\title{
Metoprolol Succinate
}

National Cancer Institute

\section{Source}

National Cancer Institute. Metoprolol Succinate. NCI Thesaurus. Code C29254.

The succinate salt form of metoprolol, a cardioselective competitive beta-1 adrenergic receptor antag onist with antihypertensive properties and devoid of intrinsic sympathomimetic activity. Metoprolol succinate antagonizes beta 1-adrenergic receptors in the myocardium, thereby reducing the rate and force of myocardial contraction, and consequently a diminished cardiac output. This agent may also reduce the secretion of renin with subsequent reduction in levels of ang iotensin II thus decreasing sympathetic activation, including vasoconstriction, aldosterone secretion. 